\title{
Environmental Management Accounting (EMA) Adoption Level among Listed Manufacturing Companies in Sri Lanka: Institutional Theory Perspective
}

\section{*H B P Chathurangani}

\author{
K J S Madhusanka
}

\begin{abstract}
This study investigates about the relationship between institutional pressure and environmental management accounting (EMA) adoption level by applying new institutional sociology perspective to assess the pressures for EMA adoption level with reference to 38 listed manufacturing companies in Colombo Stock Exchange (CSE) in Sri Lanka, based on convenient sampling method. Data were collected through structured questionnaire distributing via e-mail and postal mail for accountant or financial managers as respondents. Reliability analysis, descriptive analysis and inferential analysis were applied to analyze the data and three hypotheses were tested by multiple regression analysis. Those hypotheses were constructed to reveal about coercive isomorphism, normative pressure and mimetic processes are positively influence for EMA adoption level. The results indicate the influences of education or/and training, and political or/and legitimacy are positively pressure for the adoption of EMA; although, the pressures on standard responses to uncertainty is insignificant for EMA adoption. In addition, Coercive isomorphism; responses to political influence or/ and legitimacy influences play vital role in pressuring on EMA adoption. Further findings supports to the practical implications of Accountant role and political/ legitimacy influences are important in managing environmental issues in an organization. This study has made preliminary understanding for the new institutional sociology perspective concerning the type of pressure that influences and, provides useful contribution to the present knowledge by exploring more explanations for environmental management accounting adoption in an unexplored context in Sri Lanka.
\end{abstract}

Key words: Environmental management accounting, Institutional theory, manufacturing companies.

\section{Introduction}

EMA is "the management of environmental and economic performance through the development and implementation of appropriate EA practices (IFAC, 2005). Awareness regarding EMA adoption has been increased throughout the world by attracting the attention and interest of the managers as it is supportive mechanism to manage environmental performance. From half decade onwards, Sri Lanka creates an attitude on customer's mind to purchase eco-friendly products or purchase products from the business organizations which operate environmental friendly. In order to that business organizations tend to provide strategies to protect environment while operating their business activities. This sustainability practices guide to the business organizations to being as green towards practices.

When considering the South Asian countries there are twenty percent of population exist from whole over the world and only have five percent world's land (United Nation Environment Program (UNEP) and 
Development Alternatives, 2008);(South Asia environment outlook, 2009);(South Asia Co-operative Environment Programme, 2014) indicates that the resources are not sufficient for the South Asian population. It improves stiffen by misbehavior attitude of humans. It creates to suffer with many natural disasters resulting among the world's 15 most polluted cities, 13 are in Asia (Ilepeuma, 2000). For an example previous two three years there were Salawa army camp explosion, Aranayake and Samasara landslides, Meethotamulla garbage mountain collapse, drought in North and North Central provinces and flood in many districts (Sabaragamuwa, Western province etc.). Due to those reasons there must proper procedure for the environmental performances. The importance of adopting environmental management accounting is essential for an organization, because of above stated details in Sri Lankan context in adopting of EMA.

Manufacturing sector is sub sector of the industry sector which contributes to the country's economy by playing an immensely role in a country's economic and social transformation process. The development of the manufacturing sector can contribute to eradicate the poverty, create quality of the employment opportunities, increase export income, as well as develop technological capabilities and productive capacities of the economy to support growth. Therefore industry sector is most important to an economy like Sri Lanka; the second largest contributor after the service sector.Central Bank report (2016) stated manufacturing industry was contributed $15.4 \%$ to the Gross Domestic Products (GDP) in 2016. The importance of adopting EMA among manufacturing companies in Sri Lanka is their closely and directly transact with the environment.

Within Sri Lankan context Gunarathne and Alahakoon (2016) stated that there is no comprehensive and systematic adoption of EMA. Even EMA is more important accounting practice that a business organization should adopt. According to that this study is completely assess how these pressures relate to adopt EMA among listed manufacturing companies in Sri Lanka.

According to the researcher's sight, the research study is providing greater significance and high importance in the current and further studies. Because, the importance and adoption of EMA is still in minor stage in developing countries even, developed counties almost are practiced. Selecting new sociology institutional perspective also is rare theory to assess EMA adoption within both developing and developed countries.

This study is intended to discover the extents of institutional pressures are influence to adopt EMA in the manufacturing companies. The study is applied new sociology institutional perspective to demonstrate EMA adoption level. The level of EMA adoption depends on three institutional pressures, Such as coercive isomorphism, normative pressure and mimetic processes. The scope of the study is manufacturing companies. Due to the nature of the operation and importance to economic development manufacturing businesses' EMA adoption influencing forces should be identified. These companies are drawn from the Colombo Stock Exchanges (CSE).

\section{Literature Review}

\subsection{Environmental Management Accounting (EMA)}

The term EMA has been defined by different persons in different ways (International Federation of Accountants-IFAC (2005); Burritt et al. (2002) because, there is no universal accepted definition about environmental management accounting. According to Bartolomeo et al. (2000), the environmental management accounting is generated and analyzed both financial and non financial information for supporting internal environmental management processes and considers as a management accounting tool that is used to make internal business decisions, especially in proactive environmental management activities. EMA offers potential benefits to industry, such as the capability track, managing the flows, use of materials and energy with greater accuracy, because of that the managers can make accurate decisions for business organizations to enhance their environmental related activities (Media, 2006).

Gale (2006) mentioned reasons for the application of EMA by indicating that it is likely to lead to cost saving opportunities in the case study of Mackenzie Paper Division, which was using waste management, waste minimization and pollution prevention tools. Mackenzie Paper Division would have employed periodic environmental audits and also the researcher revealed there is corporate environmental management system (EMS) the head office, but it had not yet been implemented at that plant.

Qian et al. (2015) used institutional theory for exploring the extent of China's current economic and institutional environments to accommodate EMA development by using three larger manufacturing companies as a case study by applying coercive, cognitive and normative institutional pressures. Thefindings revealed that

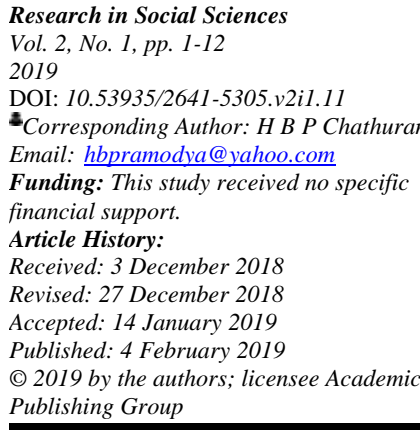




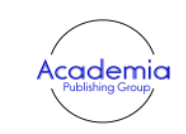

Research in Social Sciences Vol. 2, No. 1, pp. 1-12 2019

DOI: 10.53935/2641-5305.v2i1.11

Corresponding Author: H B P Chathurangani

Email: hbpramodya@yahoo.com

Funding: This study received no specific

financial support.

Article History:

Received: 3 December 2018

Revised: 27 December 2018

Accepted: 14 January 2019

Published: 4 February 2019

(C) 2019 by the authors; licensee Academic

Publishing Group there is still considerable for using of EMA in China. Corporate environmental impacts and opportunities were drowning for EMA development.

According to Kokubu and Nashioka (n.d.) examined about EMA practices in manufacturing sites in Japan. In order to clarify manufacturing sites' environmental management accounting practices, questionnaire targeted environmental report publishing firms listed on the First Section of the Tokyo Stock Exchange in four business categories: chemicals, electric appliances, pharmaceuticals, and transport machinery. The study concluded that Environmental management accounting can only be used effectively in corporate management if it is used at manufacturing sites where actual business activity takes place. It has been shown that the important matter is not simply to send data to head offices, but to make use of environmental accounting information internally and for this to happen, advice from head offices is effective. Manufacturing sites which actually use environmental accounting for internal management tends to rate the usefulness of environmental accounting more highly than those sites which do not. This fact suggests the importance of environmental management accounting for Japanese manufacturing sites.

Jamil et al. (2015) studied about environmental management practice in small and medium manufacturing firms in Malaysia. In order to that the author investigated about factors and barriers which influence the practice of EMA. This study is selected 350 samples of questionnaires sent to the SME managers. According to the findings, both MEMA and PEMA show low EMA practice in manufacturing SMEs. Financial barriers are the most dominant factor that caused to prevent practicing EMA. The insufficient environmental knowledge and skills restrict the integration of environmental issues into the accounting system and practice. Finally it concluded that absence of a guide to EMA is also another barrier to the integration of environmental issues into the existing accounting system and practices.

According to Gunarathne and Alahakoon (2016) provided a snapshot regarding EMA practices and their diffusion with the view of author's experience with several industries. It studied about use of EMA tools and techniques in Sri Lankan organizations and how the way it diffused through adopters and propagators. The authors concluded that there is no comprehensive and systematic adoption of EMA in Sri Lanka.

\subsection{Institutional Theory}

The theory is beneficial by addressing the role of institutions on the behavior of the company and their employees. In order to that Jalaludin et al. (2011) stated the institutional theory is explored the way an organizational structure and actions are shaped by institutional forces.

Moll et al. (2006) stated the new institutional sociology perspective offers some insights into understanding the practice of accounting based on a broad variety of areas including cognitive science, cultural studies, psychology and anthropology, while at the same time discarding the rational actor perspective. It takes the view that the adoption of a particular accounting system is largely driven by the need of the organization to conform to external pressures as opposed to the desire for increased internal efficiency (Covaleski and Dirsmith, 1988; Moll et al., 2006). Scott (1995) stated institutions as regulative, normative and cognitive structures and activities that provide stability and meaning for social behavior.

According to DiMaggio and Powell (1983) there is an important element in this theory that is isomorphic concept.

\subsubsection{Isomorphic Concept}

Mayer and Rowan (1977); DiMaggio and Powell (1983) expressed about isomorphic concept as organizations are structured by phenomena in their environments and gradually become homogenized with them. According to Meyer and Rowan (1977) organizations will then be able to demonstrate that they are not only legitimate but stable by social definition. Therefore, this will encourage greater commitment from internal participants and external constituents. This point reflects the significance of the isomorphic process in promoting an organization's success and survival. Coercive pressures, mimetic pressures and normative pressures are the three mechanisms that caused for changing institutional isomorphic (Nyide \&Lekhanya, 2017).

\subsubsection{Coercive Pressures}

According to DiMaggio and Powell (1983), coercive pressures are explained as regulatory compliance to existing regulation. In other word it can occurs in response to political influence or legitimacy problems. 
Hussain and Gunasekaran (2002) stated that coercive pressures reflect the enforcing and regulative aspects of certain institutions and the institutional features of environments are receiving increasing attention as important determinants of the structure and functioning of organization. The author studied about non financial performance measurement practices in management accounting in Finnish banks and financial institutions (BFI) by using case study approach. Findings revealed that central bank and socioeconomic and political institutions dimensions found to be the most influential factors.

Qian et al. (2015) applied coercive institutions in manifested though increasing regulatory pressure on environmental management, increasing pressures for more EMA information for compliance with the introduction of certified environment management systems. According to the findings of this research study, the author stated that government concerns about the managers' perception about how and to what extent companies must react to the environmental pressures and findings revealed that the government in China is not only the political authority, but also acts as an "invisible" manager of companies. When analyzing about the need of coercive information ne for environmental certifications, in recently increase in adopting of environmental management system under ISO 14001 has provided a rational foundation in environmental information system.

According to Jalaludin et al. (2011) highlighted that accountants were pressured by their customers, shareholders, head office and government in terms of environmental performance. This pressure will then influence company policy and subsequently, affect accountants' management accounting practice, including EMA adoption. As described above, the author found that according to shareholders pressure a Japanese holding company has its own company policy regarding environmental related matters.

Jamil et al. (2015) identified that coercive factors significantly influence to the EMA practice. Pollution incidents law and government pollutions standards were highly influence to the EMA practice in Malaysia SME manufacturing organizations.

\subsubsection{Normative Pressures}

According to DiMaggio and Powell (1983), normative pressures arising from professionalism by emphasized the importance of voluntary adoption to mitigate coercive pressures with consisting two sources of professionalism: Education; and Professional networking.

According to Hussain and Gunasekaran (2002) management's competence, management's strategic orientation and top management and corporate culture were applied as dimensions to measure normative pressures in non-financial performance measurements. Findings provided management's competence and management's strategic orientation were affected to the Finnish banks/ financial institutions.

Qian et al. (2015) discussed about normative barriers that related to EMA development in China by applying observation and interviews in three large manufacturing companies.Findings indicated that normative pressure was minimal and it largely constrained by a several number of institutional barriers.

According to Jamil et al. (2015) applied motivation from staff training and membership of an accounting body as dimensions in normative pressures. The author concluded that there was no significant influence EMA by normative pressures to small and medium manufacturing firms in Malaysia.

Jalaudin et al. (2011) found normative pressure provides a significantly affect to the EMA adoption level. The questionnaire survey found a significant relation between normative pressure and EMA adoption level, while the post-survey interviews revealed the opposite by indicating the respondentsdo not faced any normative pressure concerning environmental matters in their accounting practices. The respondent accountants revealed that their work is highly structured and it dictated by their education background and by their training that they have received.

According to Hussain and Hoque (2002) explained that management lack of knowledge of modern performance measurement systems like balance scorecard approach prevented them from measuring both financial and non-financial performance at the same time, with equal importance. The research findings provided that top management's attitude also influenced for the non-financial performance measurement practices.

Setthasakko (2010) found that the success of implementing corporate environmental management depends on the ability to manage humans. Thai employees tend to accept a hierarchical order and recognize top management roles in making decisions and solving problems. 


\subsubsection{Mimetic Pressures}

DiMaggio and Powell (1983) expressed that Mimetic pressures are occurred because of responding to proven techniques or practices when faced with ambiguous and uncertain situations. On the other hand, mimetic processes are a result of standard response to uncertaintyand these elements cause change in organization. According to Zucker (1987) stated when organizations respond to external institutional pressure, they protect their technical activities through decoupling elements of structure from other activities and from each other, thus reducing their efficiency.

According to Hussain and Gunasekaran (2002) applied integration of costing, performance measurement system with strategy and copying best practice from other organizations as dimensions to measure mimetic pressures how influence to the non financial performance measurement in Finnish bank and financial institutions. According to finding of four banks and financial institutions, it provided those two dimensions were directly influence to NFPM in BFI. It explained that because of lack of integration issues creates difficulty in achieving the target to make customer satisfied. The links between the strategies of cost, management accounting system and performance measurement can fulfill the objective to measure not only non financial performance but also financial performance, which significantly lessens the tendency of copying best practice management accounting system from other organizations (Hussain and Hoque, 2002).

Jalaludin et al. (2011) argued there was insignificant relationship between mimetic processes and EMA adoption as per questionnaire survey and post survey interviews. It expressed that the non existence of uncertainty in terms of accounting practice related to environmental issues because the availability of company policy as well as advice from consultants hired to provide guidance on environmental related issues. Therefore, this will lead to reduce the need for copying management accounting practice from other organizations. Jamil et al. (2015) also concluded that there was an insignificant relationship between mimetic pressures and EMA practice in small and medium manufacturing firms in Malaysia.

Larojan et al. (2014) stated that in the context of Sri Lankan organizational view, research on of EMA is still at its initial stage and Gunarathne and Alahakoon (2016) stated that the authors do not find a comprehensive and systematic adoption in Sri Lanka. It revealed that in Sri Lankan context EMA is still developing topic. Also further, the influence of factors arising from the manufacturing environment on EMA adoption has not yet been examined within the context of Sri Lanka. Therefore this study is reviewing how new sociology perspective institutional forces can influence to adopt EMA in listed manufacturing companies by identifying relationship between EMA adoption level and institutional pressures. The following hypotheses are developed.

$\mathrm{H}_{\mathrm{a} 1}=$ There is a positive relationship between EMA adoption level and coercive isomorphism.

$\mathrm{H}_{\mathrm{a} 2}=$ There is a positive relationship between EMA adoption level and normative pressure.

$\mathrm{H}_{\mathrm{a} 3}=$ There is a positive relationship between EMA adoption level and mimetic pressure.

\section{Results and Discussion}

\subsection{Research Method}

This research is classified as quantitative and explanatory research which used to identify the relationship between institutional pressure and EMA adoption. 38 listed manufacturing firms registered in Colombo Stock Exchange (CSE) in Sri Lanka (2017, August 11) were applied based on convenient sampling method. Structured questionnaire was appointed to collect data from Accountant or Financial Manager of the sample listed manufacturing companies was being as respondents.

\subsubsection{The Sample}

According to Burritt et al. (2002) stated as the person in charge of the financial measures of the company activities, including those that are environment-related, the views of the accountants are essential in getting clear evidence regarding EMA adoption. Most of accountant or financial managers are at the age of 20 to 35 years. It discovers that there is a possibility to join top management level at lower age and vast facility to recruit for the company's top level manager because of professional courses. Table 1summarizes selected characteristics of the respondents. About 42 per cent of the respondents of highest amount had been employed with their present employers for more than five years. This suggests that the respondents are sufficiently knowledgeable regarding the companies' practices.

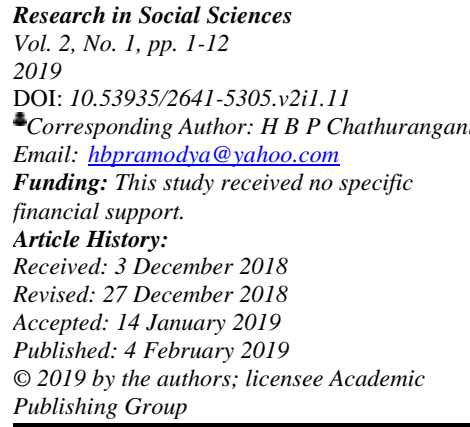


Table-1. Profile of Respondents

\begin{tabular}{lrr}
\hline Description & Frequency & Percentage \\
\hline Age (Years) & 21 & 55.3 \\
$\mathbf{2 0 - 3 5}$ & 11 & 28.9 \\
$\mathbf{3 6 - 5 0}$ & 4 & 10.5 \\
$\mathbf{5 1 - 6 5}$ & 2 & 5.3 \\
Missing & & \\
Higher Education & 12 & 31.6 \\
Bachelor Degree & 5 & 13.2 \\
Master's Degree/ PhD & 20 & 52.6 \\
Professional & 1 & 2.6 \\
Missing & & \\
Number of years in the company & 7 & 18.4 \\
Below 1 year & 14 & 36.8 \\
$\mathbf{1 - 5}$ years & 6 & 15.8 \\
6-10 years & 9 & 23.7 \\
11-20 years & 1 & 2.6 \\
Above 20 years & 1 & 2.6 \\
Missing & & 26.3 \\
Number of years in current position & 10 & 47.4 \\
Below 1 year & 18 & 23.7 \\
1-5 years & 9 & \\
6-10 years & & \\
\hline
\end{tabular}

In the present study, the unit of analysis is the organization. The manufacturing companiesthat participated in the survey comprised various industries mentioned in below Table 2 ,

Table-2. Profile of Sample Companies

\begin{tabular}{lrr}
\hline & Frequency & Percentage \\
\hline Sector of operation & 2 & 5.3 \\
Chemical and wood & 13 & 34.2 \\
Plastic, rubber and metal & 5 & 13.2 \\
Electrical and electronics & 3 & 7.9 \\
Automotive and machinery & 4 & 10.5 \\
Building materials & 6 & 15.8 \\
Food and tobacco & 2 & 5.3 \\
Others & 3 & 7.9 \\
No information & 1 & 2.6 \\
Missing & & \\
Number of employees & 5 & 13.2 \\
0-50 & 12 & 31.6 \\
$\mathbf{5 1 - 1 5 0}$ & 5 & 13.2 \\
$\mathbf{1 5 1 - 3 0 0}$ & 11 & 28.9 \\
$\mathbf{3 0 1 - 1 0 0 0}$ & 5 & 13.2 \\
\hline Above 1000 & 5 & \\
\hline
\end{tabular}

\subsection{Descriptive Analysis}

Research in Social Sciences Vol. 2, No. 1, pp. 1-12

2019

DOI: $10.53935 / 2641-5305, v 2 i 1.11$

Corresponding Author: H B P Chathurangani Email: hbpramodya@yahoo.com Funding: This study received no specific financial support.

Article History:

Received: 3 December 2018 Revised: 27 December 2018 Accepted: 14 January 2019 Published: 4 February 2019 () 2019 by the authors; licensee Academic Publishing Group

Table-3. Descriptive Statistical Analysis for Variables

\begin{tabular}{llrrrr}
\hline & $N$ & Minimum & Maximum & Mean & Std. Deviation \\
\hline Coercive isomorphism & 38 & 2.75 & 4.50 & 3.9013 & .59207 \\
Mimetic processes & 38 & 1.50 & 4.25 & 3.0789 & .82835 \\
Normative pressures & 38 & 1.00 & 4.00 & 2.3289 & .99510 \\
Level of adoption EMA & 38 & 1.15 & 4.31 & 2.4372 & .77999 \\
Valid N (list wise) & 38 & & & & \\
\hline
\end{tabular}

Source: Survey Data (2017) 
According to table 3 the mean score for level of adoption EMA shows a low EMA adoption level as mean value is 2.4372 provided that accountant or financial managers do not practice much in environmental management system of the companies. The mean score for coercive isomorphism and mimetic processes denote 3.9013 and 3.0789 respectively, and highest value indicatedthat respondents believe they face moderate level of institutional pressures through legitimacy or political influence and also they believe uncertainty provides moderate level of pressures. Professionalism affects relatively low influence on EMA adoption level.

\subsection{Correlation Analysis}

Table-4. Pearson Correlations

\begin{tabular}{|c|c|c|c|c|c|}
\hline & & $\begin{array}{c}\text { Coercive } \\
\text { isomorphism }\end{array}$ & $\begin{array}{c}\text { Mimetic } \\
\text { processes }\end{array}$ & $\begin{array}{l}\text { Normative } \\
\text { pressures }\end{array}$ & $E M A$ \\
\hline Coercive isomorphism & $\begin{array}{l}\text { Pearson Correlation } \\
\text { Sig. (1-tailed) }\end{array}$ & 1 & & & \\
\hline Mimetic processes & $\begin{array}{l}\text { Pearson Correlation } \\
\text { Sig. (1-tailed) }\end{array}$ & $\begin{array}{l}.140 \\
.200\end{array}$ & 1 & & \\
\hline Normative pressures & $\begin{array}{l}\text { Pearson Correlation } \\
\text { Sig. (1-tailed })\end{array}$ & $\begin{array}{l}.152 \\
.181\end{array}$ & $\begin{array}{l}.127 \\
.223\end{array}$ & 1 & \\
\hline $\begin{array}{l}\text { EMA } \\
\text { **. Correlation is signi } \\
\text { *. Correlation is signifi }\end{array}$ & $\begin{array}{l}\text { Pearson Correlation } \\
\text { Sig. (1-tailed) } \\
N \\
\text { at the } 0.01 \text { level (1-ta } \\
\text { at the } 0.05 \text { level (1-tail }\end{array}$ & $\begin{array}{r}.529^{* *} \\
.000 \\
38\end{array}$ & $\begin{array}{r}.329^{*} \\
.022 \\
38\end{array}$ & $\begin{array}{r}.498^{* *} \\
.001 \\
38\end{array}$ & 38 \\
\hline
\end{tabular}

Source: Survey Analysis (2017)

Pearson correlation was applied to test the relationship among the variables. According to table 4 the person correlation value for EMA adoption level and institutional pressure of coercive isomorphism was 0.529 , normative pressures were 0.498 and mimetic processes was 0.329 respectively. It was the moderate positive relationship between above variables. Therefore, it can be statistically say that there was significant and moderate positive relationship between EMA adoption level with coercive isomorphism, normative pressures and mimetic processes. The correlation matrix between independent variables also confirms that there was no violation of multi-colinearity, since there was no correlation above 0.7 among independent variables.

\subsection{Regression Analysis}

3.4.1. Relationship between Dependent and Independent Variables

Table-5.1. Model summary of Independent variables and dependent variable $R \quad R$ Square Adjusted R Square Std. Error of the Estimate

\begin{tabular}{lcccc}
\hline Model & $R$ & $R$ Square & Adjusted R Square & Std. Error of the Estimate \\
\hline 1 & $.709^{a}$ & .503 & .459 & .57355 \\
a. Predictors: (Constant), Normative pressures, Mimetic processes, Coercive isomorphism & \\
\hline
\end{tabular}

Source: Survey Data (2017)

As per the results of above table 5.1, the $\mathrm{R}$ value shows the simple correlation and it was 0.709 . According to the above result, 70.9\% of EMA adoption level among manufacturing companies was described by the independent variables taken under the model 1 and remaining $29.1 \%$ of EMA adoption level is described by other factors which are beyond in the study. The R Square value is 0.503 which means $50.3 \%$ of 
EMA adoption level can be explained by coercive isomorphism, mimetic processes and normative pressures.

Table-5.2. ANOVA result of Independent variables and dependent variable

\begin{tabular}{|c|c|c|c|c|c|c|}
\hline Model & & Sum of Squares & $d f$ & Mean Square & $F$ & Sig. \\
\hline \multirow{3}{*}{1} & Regression & 11.325 & 3 & 3.775 & \multirow[t]{4}{*}{11.476} & \multirow[t]{4}{*}{$.000^{a}$} \\
\hline & Residual & 11.185 & 34 & \multirow[t]{2}{*}{.329} & & \\
\hline & Total & 22.510 & 37 & & & \\
\hline \multicolumn{5}{|c|}{$\begin{array}{l}\text { a. Predictors:(Constant), Normative pressures, Mimetic processes, Coercive isomorphism } \\
\text { b. EMA adoption level }\end{array}$} & & \\
\hline
\end{tabular}

According to the above ANOVA table, the total variance is the sum of both regression and residual variability $(22.510=11.325+11.185)$. It is represented by significant relationship of coercive isomorphism, mimetic processes and normative pressures can be used to model influence of EMA adoption level.

\begin{tabular}{|c|c|c|c|c|c|c|}
\hline \multirow{2}{*}{\multicolumn{2}{|c|}{ Model }} & \multicolumn{2}{|c|}{ Unstandardized Coefficients } & \multirow{2}{*}{$\begin{array}{c}\begin{array}{c}\text { Standardized } \\
\text { Coefficients }\end{array} \\
\text { Beta }\end{array}$} & \multirow[t]{2}{*}{$\mathrm{t}$} & \multirow[t]{2}{*}{ Sig. } \\
\hline & & B & Std. Error & & & \\
\hline \multirow{4}{*}{1} & (Constant) & -1.171 & .689 & & -1.699 & .098 \\
\hline & Coercive isomorphism & .575 & .162 & 437 & 3.543 & .001 \\
\hline & Normative pressures & .317 & .096 & .404 & 3.284 & .002 \\
\hline & $\begin{array}{l}\text { Mimetic processes } \\
\text { Ment }\end{array}$ & level & .166 & .216 & 1.759 & .088 \\
\hline
\end{tabular}

Coefficient table show the intercept (constant) and predictor variable in regression equation which is, $\gamma=\beta_{0}+\beta_{1} \chi_{1}+\beta_{2} \chi_{2}+\beta_{3} \chi_{3}+\epsilon_{\mathrm{i}}$

Dependent and independent variables of the research had included in this regression equation when entered values coefficient table for the follow regression equation. Where, $\beta_{1}=$ Coercive isomorphism, $\beta_{2}=$ Normative pressures, $\beta_{3}=$ Mimetic processes and $\gamma=$ EMA adoption level. According to the results of regression analysis can be developed the regression model as follows.

$\gamma=(1.171)+0.575 \beta_{1}+0.317 \beta_{2}+0.203 \beta_{3}+0.689$

Multiple regression analysis was applied to test hypothesis since, it provides a more detailed description about the relationship between the dependent and independent variable/s. Above Table 5.3 demonstrate the results of the coefficient by regression analysis.

$\mathrm{H}_{\mathrm{a} 1}=$ There is a positive relationship between EMA adoption level and coercive isomorphism.

According to above coefficient table model 1, regression coefficient of EMA adoption level and coercive isomorphism was 0.001 indicating significant positive relationship between EMA adoption level and coercive isomorphism.Qian et al. (2015) stated that the government provides a strong effect on managers' perception about how and unto what extent companies must react to environmental pressures. According to Hussain and Gunasekaran (2002) stated coercive pressures reflect the enforcing and regulative aspects of certain institutions and the institutional features of environments are receiving increasing attention as important determinants of the structure and functioning of organization. Jamil et al. (2015) stated there was a significant positive influence on EMA adoption by coercive isomorphism.

Jalaludin et al., (2011) findings rejected the relationship between coercive isomorphism and EMA adoption level, because there was no evidence to support from the questionnaire although, post survey interview revealed the opposite.

$\mathrm{H}_{\mathrm{a} 2}=$ There is a positive relationship between EMA adoption level and normative pressure.

According to above coefficient table model 1, regression coefficient of EMA adoption level and normative pressures was 0.002 indicating significant positive relationship between EMA adoption level and normative pressures.According to Hussain and Gunasekaran (2002) concluded management's competence and management's strategic orientation were affected to the Finnish banks/ financial institutions. Jalaudin et al. (2011) found that normative pressure provides a significant relationship to affect the EMA adoption.

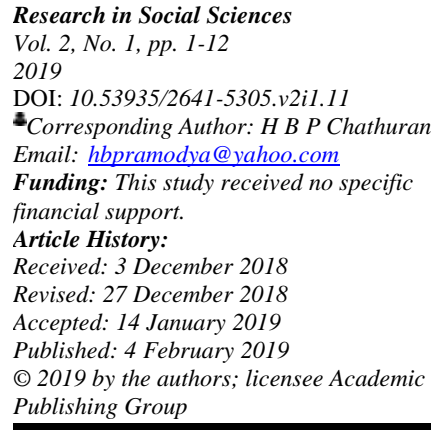


According to Siegel et al. (1997) revealed that, accountants agreed that their work was highly structured and it dictated by their educational background and the training that they have been received. Bennett et al. (2004) and Fogarty and Rogers (2005) stated as accountants, they are naturally responsive towards information provided from networking, especially with other fellow accountants and the association that they are registered with.

Although Jamil et al. (2015) conclude there was no significant influence EMA by normative pressures to small and medium manufacturing firms in Malaysia.

$\mathrm{H}_{\mathrm{a} 3}=$ There is a positive relationship between EMA adoption level and mimetic pressure.

According to above coefficient table model 1, regression coefficient of EMA adoption level and mimetic processes was 0.088 which is not significant at 0.05 . It provides positive relationship between EMA adoption level and mimetic processes but it is not significant.According to Hussain and Hoque (2002) stated there was significantly lessens the tendency of copying best practice management accounting system from other organizations although, Jalaludin et al. (2011) and Jamil et al. (2015) concluded that there was an insignificant relationship between mimetic pressures and EMA practice in small and medium manufacturing firms in Malaysia.

\section{Conclusion}

Understanding the type of relationship between institutional pressure and EMA adoption level among listed manufacturing companies in Sri Lanka revealed that, there are statistically significant and moderate positive relationships between thecoercive isomorphism, normative pressures and mimetic processeswith EMA adoption according to the correlation results. The second research objective was related to understand which institutional forces influence to adopt EMA among listed manufacturing companies in Sri Lanka. As findings coercive isomorphism which described company customers, shareholders, labor union, head office, local communities, environmental groups, financial institutions, governmental environmental related standards, environmental regulations and complying with environmental law are pressuring manufacturing companies to adopt environmental management accounting in Sri Lanka and normative pressures which has been examined through accounting staff for training with regarding environmental practices and company's environmental practices have been influenced by membership in the accounting body influence for EMA adoption. In briefly, the present study revealed that coercive isomorphism and normative pressures influencing EMA adoption among the sample manufacturing companies in Sri Lanka. In other words, policy makers and education have influenced to adopt EMA.Final research objective was related to identify which institutional force is most important or find out the dominant force that influence to adopt EMA among listed manufacturing companies in Sri Lanka. According to that, from the perspective of the new institutional sociology, it can be argued that legislation and regulation play vital role influencing respondents with regard to EMA adoption among listed manufacturing companies in Sri Lanka. Government laws and political influences provide dominant factor to adopt EMA.

The present study reveals that there is low level of EMA adoption among listed manufacturing companies in Sri Lanka and regulatory compliance to existing regulation (Coercive isomorphism) and educational and professional network (Normative pressure) significantly positively influence to adopt EMA, among them coercive isomorphism is the most forceful or dominant force which influence to adopt EMA among random sample of 41 listed manufacturing companies in Sri Lanka. Theses weaknesses can be overcome through issuing proper guidelines and rules, establishing better EMA framework by motivating adoption of EMA among professional memberships. Hence, present study it realized that in Sri Lanka has lack of EMA adoption.Increase awareness of adopting an EMS and encourage adopting EMA by conferring awards leads to enhance the establishment of EMS among listed manufacturing companies in Sri Lanka.

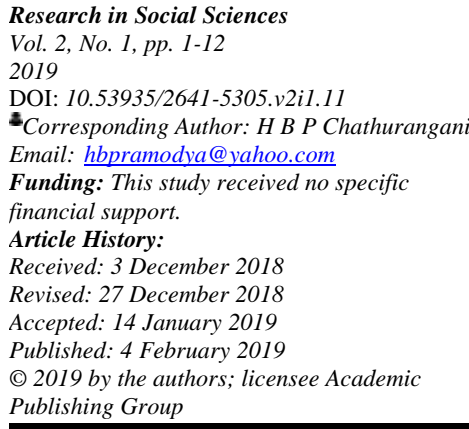

\section{References}

Abiola, J. O., \& Ashamu, S. O. (2012). Environmental Management Accounting Practice in Nigeria : National Petroleum Corporation ( Nnpc ). European Scientific Journal, 8(9): 76-93.

Bartolomeo, M., Bennett, M., Bouma, J. J., Heydkamp, P., James, P., \& Wolters, T. (2000). Environmental management accounting in Europe: current practice and future potential. European Accounting Review, 9(1): 31-52. Available at: https://doi.org/10.1080/096381800407932.

Bartolomeo, M., M. Bennett \& P. James (1998). Eco-management accounting - a framework for analysis and action UK Centre for Environment and Economic Development, Cambridge and University of Wolverhampton 
Bennett, M., Bouma, J. J., \& Ciccozzi, E. (2004). An institutional perspective on the transfer of accounting knowledge: a case study. Accounting Education, 13(3): 329-346. Available at: https://doi.org/10.1080/0963928042000273807

Bracci, E., \& Maran, L. (2013). Environmental management and regulation: pitfalls of environmental accounting? Management of Environmental Quality: An International Journal, 24(4): 538-554. Available at: https://doi.org/10.1108/MEQ-04-2012-0027

Burrit, Rogger, L., Hahn, T., \& Schaltegger, S. (2002). Towards a comprehensive framework for environmental management accounting - Links between business actors and environmental management accounting tool. Australian Accounting Review, 12(2): 39-50.

Burritt, R. L. (2004). Environmental management accounting: Roadblocks on the way to the green and pleasant land. Business Strategy and the Environment, 13(1): 13-32. Available at: https://doi.org/10.1002/bse.379

Burritt, R.L \& Saka, C. (2006). Environmental management accounting applications and eco-efficiency: Case studies from Japan. Journal of Cleaner Production, 14: 1262-1275.

Central Bank of Sri Lanka (CBSL) (2016). Annual Report 2016, CBSL, Colombo

Colombo Stock Exchange (CSE) Official web site. Available from: https://www.cse.lk/home/CSESectors

Chang, H. (2007). Environmental Management Accounting Within Universities: Current State and Future Potential. Business, (November).

Chang, H.-C. (2013). Environmental management accounting in the Taiwanese higher education sector: Issues and opportunities. International Journal of Sustainability in Higher Education, 14(2): 133-145. Available at: https://doi.org/10.1108/14676371311312851

Christ, K. L., \& Burritt, R. L. (2013). Environmental management accounting: The significance of contingent variables for adoption. Journal of Cleaner Production, 41: 163-173. Available at: https://doi.org/10.1016/j.jclepro.2012.10.007

Conservation International (CI) (2005). Biodiversity Hotspots, CI, Washington.

Cooray, N., Murshidha, F., Senanayake, N., Prashanty, R., Rathnasinghe, U., \& Dharmika, J. (2014). Adopting and a nd Implementing Waste Management Practices in t he Printing Industry: A Sri Lankan Case. pp: 102-114.

Covaleski, Mark A.Dirsmith, M. W., Covaleski, M. a, \& Dirsmith, M. W. (1988). An Institutional Perspective on the Rise, Social Transformation, and Fall of a University Budget Category. Administrative Science Quarterly, 33(4): 562-587. Available at: https://doi.org/10.2307/2392644

Dimaggio, P. J., Powell, W. W., Review, A. S., Apr, N., \& Powell, W. (1983). The Iron Cage Revisited: Institutional Isomorphism and Collective Rationality in Organizational Fields. American Sociological Review, 48(2): 147160. Available at: https://doi.org/10.2307/2095101

Doorasamy, M. (2015). Theoretical developments in environmental management accounting and the role and importance of MFCA. Foundations of Management, 7(1): 37-52. Available at: https://doi.org/10.1515/fman-2015-0024

Ferreira, A., Moulang, C., \& Hendro, B. (2010). Environmental management accounting and innovation: an exploratory analysis. Accounting, Auditing \& Accountability Journal, 23(7): 920-948. Available at: https://doi.org/10.1108/09513571011080180

Frost, G. R., \& Wilmshurst, T. D. (2000). The Adoption of Environmental-Related Management Accounting: An Analysis of Corporate Environmental Sensitivity. Accounting Forum., 24(4): 344-365. Available at: https://doi.org/10.1111/1467-6303.00045

Gale, R. (2006). Environmental costs at a Canadian paper mill: a case study of Environmental Management Accounting (EMA). Journal of Cleaner Production, 14(14)L 1237-1251. Available at: https://doi.org/10.1016/j.jclepro.2005.08.010

Gray, R. H. (1994). Corporate Reporting for Sustainable Development: Accounting for Sustainability in 2000AD. Environmental Values, 3(1): 17-45. Available at https://doi.org/10.3197/096327194776679782

Gray, R., \& Bebbington, J. (2000). Environmental accounting, managerialism and sustainability: Is the planet safe in the hands of business and accounting? Advances in Environmental Accounting and Management, 1: 1-44. Available at: https://doi.org/10.1016/S1479-3598(00)01004-9

Gunarathne, A. D. N., \& Alahakoon, Y. (2016). Environmental Management Accounting Practices and their Diffusion: The Sri Lankan Experience. NSBM Journal of Management, 2(1): 1. Available at: https://doi.org/10.4038/nsbmjm.v2i1.18

Research in Social Sciences Vol. 2, No. 1, pp. 1-12

DOI: 10.53935/2641-5305.v2i1.11

Corresponding Author: H B P Chathurangani Email: hbprang Author: H B P Chat Funding: This study received no specific financial support.

Article History:

Received: 3 December 2018

Revised: 27 December 2018

Accepted: 14 January 2019

Published: 4 February 2019

(C) 2019 by the authors; licensee Academic

Publishing Group

Gunarathne, N \& Lee, KH (2015). Environmental management accounting (EMA) for environmental management and organizational change. Journal of Accounting \& Organizational Change, 11(3): $362-383$.

Hawley, A. (1968).Human ecology.In D.L. Sills (ed.) International Encyclopedia of the Social Sciences 328-37. New York: Macmillan.

Hoozée, S. (2011). Exploring the interface between environmental reporting and management accounting, 2011(September): 1-37.

Hussain, M., \& Gunasekaran, A. (2002). Non-financial management accounting measures in Finnish financial institutions. European Business Review, 14(3): 210-229. Available at: https://doi.org/10.1108/09555340210427094 
Hussain, M.M. \& Hoque, Z. (2002).Understanding non-financial performance measurement practices in Japanese banks: a new institutional sociology perspective", Accounting and Accountability Journal, 15(2): 162-183.

Illeperuma, O. a. (2000). Environmental Pollution In Sri Lanka:A Revies. J.Natin.Sci.Foundation Sri Lanka, 28(4): 301325 .

IFAC (2005). International Guidance Document: EMA. International Federation of Accountants, New York.

Ismail, M. S., Ramli, A., \& Darus, F. (2014). Environmental Management Accounting Practices and Islamic Corporate Social Responsibility Compliance: Evidence from ISO14001 Companies. Procedia - Social and Behavioral Sciences, 145: 343-351. Available at: https://doi.org/10.1016/j.sbspro.2014.06.043

Ismail, N. A., \& King, M. (2007). Factors influencing the alignment of accounting information systems in small and medium sized Malaysian manufacturing firms. Journal of Information Systems and Small Business, 1(1): 1-20.

ISO 14001 (2015). Available from https://www.iso.org/standard/60857.html

Jalaludin, D., Sulaiman, M., \& Nazli Nik Ahmad, N. (2011). Understanding environmental management accounting (EMA) adoption: a new institutional sociology perspective. Social Responsibility Journal, 7(4): 540-557. Available at: https://doi.org/10.1108/17471111111175128

Jalaludin, D., Sulaiman, M., \& Nik Ahmad, N. N. (2010). Environmental Managament Accounting: An Empirical Investigation of Companies in Malaysia. Journal of Asia-Pacific Centre for Environmental Accountability, 16(3), 31-45.

Jalaludin, D., Sulaiman, M., \& Nik Ahmad, N. N. N. (2011). Environmental Management Accounting: A Theoretical Framework.

Jamil, C. Z. M., Mohamed, R., Muhammad, F., \& Ali, A. (2015). Environmental Management Accounting Practices in Small Medium Manufacturing Firms. Procedia - Social and Behavioral Sciences, 172: 619-626. https://doi.org/10.1016/j.sbspro.2015.01.411

Kim, J.D. (2002). A guideline for the measurement and reporting of environmental costs, in Bennett, M., Bouma, J.J. and Wolters, T. (Eds), Environmental Management Accounting: Information and Institutional Developments, Kluwer Academic, Dordrecht. pp: 51-65

Klovienė, L. (2012). Institutional factors as critera for business environment identification. Economics and Management, 17(4): 1245-1251.

Kokubu, K., \& Nashioka, E. (n.d.) Environmental Management Accounting Practices in Japanese Manufactuing Sites, Graduate School of Business Administration, Kobe University, 657-8501. From Eman, G.(2006)

Kokubu, K. \& Kurasaka, T. (2002). Corporate environmental accounting: a Japanese perspective, in Bennett, M., Bouma, J.J. and Wolters, T. (Eds), Environmental Management Accounting: Informantion and Institutional Developments, Kluwer Academic, Dordrecht. pp: 161-173.

Lapsley, I., \& Pallot, J. (2000). Accounting, management and organizational change: A comparative study of local government. Management Accounting Research, 11(2): 213-229. Available at https://doi.org/10.1006/mare.2000.0129

Larojan, C., Thevaruban, J. S., Larojan, C., \& Thevaruban, J. S. (2014). Impact of Environmental Management Accounting Practices on Financial Performance of Listed Manufacturing Companies in Sri Lanka, (February): 239-246.

Lima Ribeiro, V. P., Aibar Guzmán, C., da Silva Monteiro, S. M., \& Aibar Guzmán, B. (2012). Determining factors of environmental management practices in Portuguese local entities. Management of Environmental Quality: An International Journal, 23(5): 486-502. Available at: https://doi.org/10.1108/14777831211255079

Media,S.,(2006). https://www.accountingweb.com/aa/auditing/what-is-environmental-accounting

Moll, J., Burns, J.\& Major, M. (2006). Institutional theoy, in Hoque, Z. (Ed.), Methodological Issues in Accounting Research: Theories and Methods, Spiramus Press, London.

Nath, P., \& Ramanathan, R. (2016). Environmental management practices, environmental technology portfolio, and environmental commitment: A content analytic approach for UK manufacturing firms. International Journal of Production Economics, 171: 427-437. Available at: https://doi.org/10.1016/j.ijpe.2015.09.040

Pagulung, Gagaring, A. (2016). Environmental management accounting: Identifying Future Potentials. Asia-Paciific Management Accounting Journal, 11(1): 80-94. Available at: https://doi.org/10.1093/acprof:oso/9780199283361.003.0017

Qian, W. (2012). Environmental Management Accounting and Supply Chain Management. Journal of Cleaner Production, 20(1): 186-187. Available at: https://doi.org/10.1016/j.jclepro.2011.07.023

Qian, W., Burritt, R., \& Chen, J. (2015). The potential for environmental management accounting development in China. Journal of Accounting \& Organizational Change, 11(3): 406-428. Available at: https://doi.org/10.1108/JAOC11-2013-0092

Qian, W., Burritt, R., \& Monroe, G. (2011). Environmental management accounting in local government. Accounting, Auditing \& Accountability Journal, 24(1): 93-128. Available at: https://doi.org/10.1108/09513571111098072

Rowe, A. L., Wehrmeyer, W., \& Rowe, A. L. (2001). Why does the Talk of Positive Environmental Values not match the Walk of Environmental Accountability in Shanghai? The Third Asian Pacific Interdisciplinary Research in 
Accounting Conference.

Sasanke, J. (2014). Sri Lankan perspective Management Accounting Competencies Required to Lead Successfully in Manufacturing Industries in Sri Lanka. Available From https://www.cimaglobal.com/Ourlocations/SriLanka/Thought-leadership/2014-

Schaltegger, S., Gibassier, D., \& Zvezdov, D. (2013). Is environmental management accounting a discipline? A bibliometric literature review. Meditari Accountancy Research, 21(1): 4-31. Available at: https://doi.org/10.1108/MEDAR-12-2012-0039

Schaltegger, S., Hahn, T., \& Burritt, R. (2000). Environmental management accounting: Overview and main approaches.

Schaltegger, S., Hahn, T., \& Burritt, R. (2006).Sustainability accounting and reporting. Available from http://www.springer.com/gp/book/9781402040795

Schwarz, H. (n.d.). Research on Sustainability Management Accounting - The Austrian Approach.Austrian Federal Ministry of Transport, Innovation and Technology, from Graz (2006).

Scott, R.W. (1995).Institutions and Organizations.Ideas, Interests and Identities. Available From https://www.cairn.info/revue-management-2014-2-page-136.htm

Sekaran, U. (2007). Research Method for Business A Skill bulding approach fourth edition

Setthasakko, W. (2010). Barriers to the development of environmental management accounting. EuroMed Journal of Business, 5(3): 315-331. Available at: https://doi.org/10.1108/14502191011080836

South Asia Co-operative Environment Programme (SACEP) 2014, Post 2015 South Asia Development Agenda, SACEP, Colombo.

Tolbert, P. S., \& Zucker, L. G. (1983). Institutional Sources of Change in the Formal Structure of Organizations: The Diffusion of Civil Service Reform, 1880-1935. Administrative Science Quarterly, 28(1): 22. Available at: https://doi.org/10.2307/2392383.

UNDSD. (2003). EMA makes \$en\$e!!! Measurement for improved environmental \& economic performance: Environmental management accounti ng, 1-8.

United Nations (2016). Sustainable development goals (SDGs). Available from http://www.undp.org/content/undp/en/home/sdgoverview/post-2015-development-agenda.html. [Accessed 20 July 2016]

United Nations Environment Programme and Development Alternatives (2008). South Asia environment outlook 2009: United Nations Environment Programme (UNEP), Bangkok, South Asian Association for Regional Cooperation (SAARC),Kathamndu and Development Alternatives (DA), New Delhi.

United Nations Environment Program (UNEP) \& United Nations Industrial Development Organization (UNIDO) (1991). Audit and reduction manual for industrial emissions and waste, UNEP and UNIDO, Paris

Wiedmann, T., \& Lenzen, M. (2009). Environmental Management Accounting for Cleaner Production. Eco-Efficiency in Industry and Science, 24(January 2009), 65-90. Available at: https://doi.org/10.1007/978-1-4020-8913-8 17

Xiaomei, L.(2004). Theory and practice of environmental management accounting. International Journal of Technology Management \& Sustainable Development, 3(1): 47-57.

Zhang, J. (2014). Environmental Accounting: Theoretical Review and Enlightenment for China. Journal of Management and Sustainability, 4(1): 179-188. Available at: https://doi.org/10.5539/jms.v4n1p179.

Zucker, L. G. (1987). Institutional Theories of Organization. Ann. Rev. Sociol, 13: 443-64. Available at: https://doi.org/10.1146/annurev.soc.13.1.443.

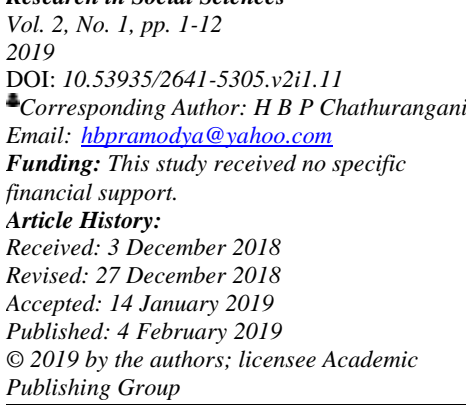

